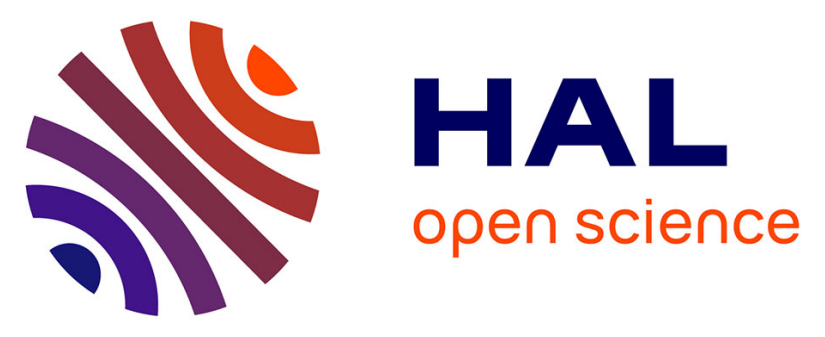

\title{
Search for the best indicators for the presence of a VPS13B gene mutation and confirmation of diagnostic criteria in a series of 34 patients genotyped for suspected Cohen syndrome
}

Salima El Chehadeh, Bernard Aral, Nadège Gigot, Christel Thauvin-Robinet, Anne Donzel, Marie-Ange Delrue, Didier Lacombe, Albert David, Lydie Burglen, Nicole Philip, et al.

\section{- To cite this version:}

Salima El Chehadeh, Bernard Aral, Nadège Gigot, Christel Thauvin-Robinet, Anne Donzel, et al.. Search for the best indicators for the presence of a VPS13B gene mutation and confirmation of diagnostic criteria in a series of 34 patients genotyped for suspected Cohen syndrome. Journal of Medical Genetics, 2010, 47 (8), pp.549. 10.1136/jmg.2009.075028 . hal-00557384

\author{
HAL Id: hal-00557384 \\ https://hal.science/hal-00557384
}

Submitted on 19 Jan 2011

HAL is a multi-disciplinary open access archive for the deposit and dissemination of scientific research documents, whether they are published or not. The documents may come from teaching and research institutions in France or abroad, or from public or private research centers.
L'archive ouverte pluridisciplinaire HAL, est destinée au dépôt et à la diffusion de documents scientifiques de niveau recherche, publiés ou non, émanant des établissements d'enseignement et de recherche français ou étrangers, des laboratoires publics ou privés. 


\section{Search for the best indicators for the presence of a VPS13B gene mutation and confirmation of diagnostic criteria in a series of 34 patients genotyped for suspected Cohen syndrome}

Salima El Chehadeh ${ }^{1}$, Bernard Aral $^{2}$, Nadège Gigot ${ }^{1,2}$, Christel Thauvin-Robinet ${ }^{1}$, Anne Donzel $^{2}$, Marie-Ange Delrue ${ }^{3}$, Didier Lacombe ${ }^{3}$, Albert David ${ }^{4}$, Lydie Burglen ${ }^{5}$, Nicole Philip $^{6}$, Anne Moncla ${ }^{6}$, Valérie Cormier-Daire ${ }^{7}$, Marlène Rio ${ }^{7}$, Patrick Edery ${ }^{8}$, Alain Verloes ${ }^{9}$, Dominique Bonneau $^{10}$, Alexandra Affenjar ${ }^{11}$, Aurélia Jacquette ${ }^{11}$, Delphine Heron ${ }^{11}$, Pierre Sarda $^{12}$, Lucille Pinson ${ }^{12}$, Bérénice Doray ${ }^{13}$, Jacqueline Vigneron ${ }^{14}$, Bruno Leheup ${ }^{14}$, AnneMarie Frances-Guidet ${ }^{15}$, Gwenaelle Dienne ${ }^{16}$, Muriel Holder $^{17}$, Alice Masurel-Paulet ${ }^{1}$, Frédéric Huet ${ }^{1}$, Jean-Raymond Teyssier ${ }^{2}$, Laurence Faivre ${ }^{1}$

1. Centre de Génétique et Centre de Référence Anomalies du Développement et Syndromes Malformatifs, Hôpital d'Enfants, CHU Dijon, France,

2. Laboratoire de Génétique Moléculaire, Plateau Technique de Biologie, CHU Dijon, France,

3. Service de Génétique Médicale, CHU Bordeaux, France,

4. Génétique Clinique, CHU Nantes, France,

5. Unité de génétique clinique et neurogénétique, CHU Armand-Trousseau, Paris, France,

6. Département de génétique médicale, CHU de Marseille, France,

7. Département de Génétique, Hôpital Necker - Enfants Malades, Paris, France,

8. Unité de génétique pédiatrique, CHU de Lyon, France,

9. Unité fonctionnelle de génétique clinique, CHU Robert Debré, Paris, France,

10. Service de génétique, CHU d'Angers, France,

11. Département de génétique, cytogénétique et embryologie, CHU Pitié-Salpêtrière, Paris, France, 12. Service de génétique médicale, CHU de Montpellier, France, 
13. Service de génétique médicale, CHU de Hautepierre, Strasbourg, France,

14. Département de Génétique, CHU Nancy, Nancy, France

15. Service de Génétique, CH Toulon, Toulon, France

16. Service de Génétique, Hôpital d'Enfants, Toulouse, France

17. Service de Génétique, Hôpital Jeanne de Flandres, Lille, France.

Key words: Cohen syndrome, VPS13B gene, neutropenia, chorioretinal dystrophy

Address for correspondence: Laurence Faivre, MD-PhD

Centre de Génétique, Hôpital d'Enfants,

10 Bd maréchal de Lattre de Tassigny

21034 Dijon Cedex, France

Tel: +33 $380295313 \quad$ Fax +33 380293266

Email: Laurence.faivre@chu-dijon.fr 


\section{ABSTRACT}

Background: Cohen syndrome is a rare autosomal recessive inherited disorder that results from mutations of the VPS $13 B$ gene. Clinical features consist of a combination of mental retardation, facial dysmorphism, post-natal microcephaly, truncal obesity, slender extremities, joint hyperextensibility, myopia, progressive chorioretinal dystrophy and intermittent neutropenia.

Patients and Methods: The aim of our study was to determine which of the above clinical features were the best indicators for the presence of VPS13B gene mutations in a series of 34 patients with suspected Cohen syndrome referred for molecular analysis of VPS13B.

Results: Fourteen VPS13B gene mutations were identified in 12 patients, and no mutation was found in 22 patients. The presence of chorioretinal dystrophy (92\% versus 32\%, $\mathrm{p}=0.0023$ ), intermittent neutropenia $(92 \%$ versus $5 \%, \mathrm{p}<0.001)$ and postnatal microcephaly $(100 \%$ versus $48 \%, \mathrm{p}=0.0045)$ was significantly higher in the group of patients with a VPS13B gene mutation compared to the group of patients without a mutation. All patients with VPS13B mutations had chorioretinal dystrophy and/or intermittent neutropenia. The Kolehmainen diagnostic criteria provided $100 \%$ sensibility and $77 \%$ specificity when applied to this series.

Conclusion: From this study and a review of more than 160 genotyped cases from the literature, we conclude that, given the large size of the gene, VPS13B screening is not indicated in the absence of chorioretinal dystrophy or neutropenia in patients aged over 5 years. The follow-up of young patients could be a satisfactory alternative unless there are some reproductive issues. 


\section{INTRODUCTION}

Cohen syndrome (CS) (OMIM 216550) is a rare autosomal recessive disorder first described in 1973, which involves a broad spectrum of clinical manifestations. ${ }^{1}$ Based on the observations of 29 Finish patients with CS, Kivitie-Kallio and Norio $^{2}$ were the first to propose the essential features for CS diagnosis prior to the identification of the $\mathrm{COHI}$ gene: (1) nonprogressive mental retardation, motor clumsiness, and microcephaly; (2) typical facial features including wave shaped eyelids, short philtrum, thick hair, and low hairline; (3) childhood hypotonia and joint hyperextensibility; (4) retinochoroidal dystrophy and myopia by 5 years of age; (5) periods of isolated neutropenia. These criteria were modified by Chandler $e t a l^{3}$ to be more applicable to young patients, when there is not yet evidence of chorioretinal dystrophy (CRD) or patients with a more heterogeneous genetic background. These authors proposed that CS could be diagnosed in the presence of at least two of the following major criteria in a child with significant learning difficulties: (1) facial gestalt, characterised by thick hair, eyebrows and eyelashes, wave shaped, downward slanting palpebral fissures, prominent, beak-shaped nose, short, upturned philtrum with grimacing expression on smiling; (2) pigmentary retinopathy; (3) neutropenia (defined as < 2000/mm3).

The VPS13B gene was subsequently identified on chromosome $8 \mathrm{q} 22-\mathrm{q} 23$. This gene is composed of 62 exons that span a genomic region of around $864 \mathrm{~kb}$ and encodes a putative transmembrane protein of 4,022 amino acids with a complex domain structure (OMIM 607817). ${ }^{4}$ Although the exact function of VPS13B protein remains unknown, homology to the Saccharomyces cerevisiae VPS13 protein suggests a role in vesicle-mediated sorting and intracellular protein trafficking. ${ }^{4}$ Since the first identification of a VPS13B gene mutation, ${ }^{4}$ more than a hundred distinct VPS13B gene mutations have been identified ${ }^{4-14}$. Following identification of the VPS13B gene, the Chandler criteria were modified by the same team, since new clinical features were noted ${ }^{7}$. Patients were considered as having Cohen syndrome 
when 6 of the following 8 criteria were fulfilled: developmental delay, microcephaly, typical facial dysmorphism, obesity and slender extremities, sociable behaviour, joint laxity, myopia/retinal degeneration and intermittent neutropenia. ${ }^{7}$ In spite of considerable genotypic variability, positive patients fulfilled the diagnostic criteria with relative clinical homogeneity. Given the increasing number of requests for molecular testing in patients with suspected CS and the very large size of the gene, the aim of our study was to determine which of the above clinical features are the best indicators for the presence of VPS13B gene mutations by comparing patients carrying VPS13B mutations with negative patients in a series of 34 patients referred for molecular testing of VPS13B in suspected CS. The results should help clinicians to evaluate whether VPS13B mutations are likely to be responsible for a clinical phenotype combining a number of features. We also evaluated the current diagnostic criteria.

\section{SUBJECTS AND METHODS}

\section{Subjects}

A total of 34 patients from 29 families were ascertained for VPS13B testing and suspected CS at the molecular diagnostic laboratory of Dijon University Hospital in France. When a sample was received for $V P S 13 B$ screening, a standardized comprehensive clinical form was sent to the referring physician. All blood samples received were screened for a VPS13B gene mutation, whether or not the patients presented the clinical criteria for the diagnosis of CS according to Chandler $e t a l^{3}$. Written informed consent was obtained according to the French regulatory requirements for genetic testing.

\section{Molecular genetic analysis}


Each blood sample was processed for DNA extraction using the "salting-out" method. ${ }^{15}$ PCR analysis and sequencing of exons and exon-intron boundaries of the VPS13B gene as well as amplification of gene sequences encoding exons 1 to 62 were performed. All PCR products were directly sequenced using a BigDye terminator kit and an ABI Genetic Analyzer 3100 capillary sequencer according to the manufacturer's instructions (Applied Biosystems, Foster City, CA, USA). Primer sequences are available on request. Corresponding reference sequences of the genomic DNA sequences of the VPS13B gene were downloaded using Ensembl Genome Browser (Accession number ENSG00000132549). The SeqScape ${ }^{\circledR}$ software v2.5 package (Applied Biosystems, Foster City, CA) was used to visualize capillary trace electropherograms, for sequence assembly and alignment, and to search for comparisons with consensus and reference sequences and variations. Depending on the analyzed exon, only between twenty and thirty bases inside the intervening sequences donor site and acceptor site from the consensus splice junction sequences are clearly investigated by the sequencing analysis program and subjected to alignment with the reference sequence. Mutation nomenclature ${ }^{16}$ numbering was based on the current Ensembl transcript (Ensembl Transcript ID ENST00000358544), with +1 as the A of the ATG initiation codon. Mutations leading to premature truncations were considered pathogenic. When a missense mutation was found, its absence was verified in 220 control chromosomes.

\section{Statistical analyses}

The proportion of clinical features of the CS spectrum in the group of patients with VPS13B gene mutations was compared with that in the group of patients with negative VPS13B sequencing, using Fisher's exact test. These analyses were possible because the age at molecular screening in the two groups was similar. 


\section{RESULTS}

\section{Clinical description}

\section{Patients with VPS13B mutations}

VPS13B mutations were found in 12 patients ( 7 males and 5 females) originating from 8 families (Table 1), comprising one consanguineous Moroccan family and 7 nonconsanguineous French families. The age range at CS suspicion was 2.5 to 43.0 years and that at genetic screening was 4.8 to 43.6 years. Except for two children aged 2.5 and 4.5 years, all patients were aged over 5 years at the time of diagnosis. The percentages of clinical features of the VPS13B spectrum are reported in Table 1. All patients had mental retardation, typical or evocative CS facial gestalt, microcephaly and slender extremities with narrow hands/feet. Truncal obesity was reported in all but one patient aged 4.5 years. CRD was reported in 11/12 patients (92\%), diagnosed on fundus examination in 5 patients and on fundus and electroretinography (ERG) in 6. CRD was absent on fundus examination in a 19-year-old girl, but ERG was not performed. Early signs of CRD were observed at ERG as early as 16 and 24 months in 2 young siblings. Myopia was present in the 9 patients for whom the information was available. Neutropenia was reported in 11/12 patients. The clinical diagnosis of CS was fulfilled in all patients according to Kolehmainen $e a^{7}$ criteria.

\section{Patients without a VPS13B mutation}

The 22 patients (7 males, 15 females) in whom no VPS13B gene mutation was found originated from 21 families, of which 1 was consanguineous. The mean age at molecular screening was $15.8 \pm 7.7$ years. The percentages of clinical features of the CS spectrum are reported in Table 1. In particular, CRD was observed in 6/19 ascertained patients. One patient had neutropenia. Kolehmainen's criteria for CS were fulfilled in 5/22. 


\section{VPS13B gene mutations}

Table 2 summarizes the mutations found in this series as well as the predicted consequence of each mutation at the protein level. A total of 14 different mutations, of which 11 have never been published, were identified in the 8 families. All mutations except 3 resulted in premature truncation (Table 2). One patient had, on the same allele on exon 56, a missense mutation

c.10880C $>\mathrm{T}$ followed by an 18-base-pair (bp) deletion (c.10883_10900delCGAGGCAGCTTGTGCACG) leading to the deletion of 6 amino acids. A homozygous missense mutation (c.4907T>A, p.I1636N) was identified in the 2 Moroccan siblings born to consanguineous parents. The pathogenic nature of the mutation was suspected for several reasons: i) isoleucine at position 1636 is a non-polar amino acid (whereas the mutant asparagine residue is polar), ii) the hydrophobic nature of the amino acid side chain at this position was $100 \%$ preserved following the alignment of proteins from different animal species (supplementary figure 1), iii) the cosegregation of the mutation in the family (supplementary figure 2), iv) the absence of this variant in 100 healthy controls. Only one truncating heterozygous VPS13B mutation was found in two patients, but these patients were considered as having CS in the presence of the typical clinical picture of the condition.

\section{Statistical analyses}

Significant differences were found between the group of patients with VPS13B mutations and the group of patients without VPS13B mutations. Indeed, the probability of finding CRD, neutropenia, microcephaly and myopia was higher in the group of patients with VPS13B mutations (Table 1). Conversely, there was no significant difference for the presence of facial gestalt, narrow extremities and truncal obesity. In this series, the sensitivity of CDR and neutropenia was $92 \%$ for both parameters whilst specificity was $68 \%$ and $95 \%$, respectively. 


\section{DISCUSSION}

The hallmarks of CS include mental retardation, facial dymorphism, chorioretinal dystrophy and neutropenia, and patients exhibit high clinical homogeneity. Following identification of the VPS13B gene, it was discovered that patients with VPS13B mutations, who did not fulfil CS clinical criteria were exceptional. ${ }^{4-12}$ Contrary to other examples in the literature ${ }^{17}$, the identification of the VPS13B gene has not made it possible to enlarge the clinical spectrum of CS. On the contrary, patients with suspected CS based on the presence of evocative facial gestalt but in the absence of ophthalmologic manifestations were reclassified as having Cohen-like syndrome, since no VPS13B mutations were found on either allele. ${ }^{8}$ Only Kolehmainen $e t a l^{7}$ has given a brief description of patients negative for VPS13B mutations. The aim of this study was to compare the clinical features of patients with VPS13B mutations with those in patients without VPS13B mutations in order to give clues to the clinician on the indication for $V P S 13 B$ screening according to the clinical phenotype, especially since molecular screening of VPS $13 B$ is a time-consuming task. We showed that all patients with VPS13B mutations had either CRD or neutropenia. The presence of microcephaly, found in all patients with VPS13B mutations in this series, was another clinical feature that can help to distinguish between CS and differential diagnoses. Conversely, there was no significant difference for the presence of evocative dysmorphism, obesity and slender extremities. Therefore, except in young children, these features, in the absence of neutropenia or CRD, are not sufficient to suspect CS. Of note, the assessment of facial gestalt is subjective whereas CRD and neutropenia may be assessed objectively. According to the London Dysmorphology DataBase, around 80 syndromes associate mental retardation and retinopathy, ${ }^{18-19}$ while only a few syndromes associate neutropenia and mental retardation. This explains why the probability of finding a VPS13B mutation in patients with neutropenia (specificity of $95 \%$ in 
our series) in a context of suspected CS is even higher than it is in patients with associated CRD (specificity of $68 \%$ in our series)

We also evaluated the clinical criteria used to diagnose CS in our series. All patients with $\mathrm{COH} 1$ mutations fulfilled the Kolehmainen criteria, and among patients with no $\mathrm{COH} 1$ mutations, 5/22 fulfilled Kolehmainen's criteria. These criteria, therefore, provided 100\% sensitivity and $77 \%$ specificity. These results are totally consistent with those reported by Kolehmainen et $a l^{7}$. All patients with VPS13B mutations fulfilled their clinical diagnostic criteria. Out of 24 patients with no VPS13B mutation and full clinical data, only 2 fulfilled their clinical criteria. Among the 22 Cohen-like patients, none had neutropenia, and only one out of the seven patients with myopia and/or retinal dystrophy had the typical facial appearance of CS - although the patient did not sufficiently fulfil the other criteria for a true diagnosis of CS.

Table 3 shows the prevalence of neutropenia in previous series reporting VPS13B mutations. This prevalence was high except in the series reported by Hennies et al ${ }^{6}$. He found only 10 patients with neutropenia in a series of 18 patients in spite of repeated haematological examinations. These results could not be assigned to any specific ethnic group or genotypephenotype correlation. Table 3 also shows the prevalence of CRD in previous series. When considering all of the 160 patients with VPS13B mutations reported in the literature and assessed for CRD and neutropenia, CRD was found in $92 \%$ of patients aged over 5 years ( $86 \%$ if the age of patients was not taken into account). The difficulties in diagnosing CRD in young patients (below 5 years of age) have been discussed by others. ${ }^{2}$ When CS is suspected, CRD may be diagnosed at the early stage of the disease using an electroretinogram (ERG) instead of, or in addition to a fundus examination. Indeed the amplitude of ERG waves may be reduced occur as soon as the photoreceptor cells are impaired while in examinations of the fundus, bull eye maculopathy or optic disc pallor with narrow vessels may be the only 
symptoms. Typical pigmentary lesions are observed later and only after cell death. This was clearly demonstrated by Chandler et al:: the early onset of CRD was evidenced using ERG in $80 \%$ of children under 5 years with suspected CS. ${ }^{3,20}$ The absence of CRD in a 19-year-old patient and its presence in 2 siblings aged 16 and 24 months in our series show the large variability in age at diagnosis of CRD in CS. These are other examples showing that this feature cannot be mandatory for the diagnosis of CS. Only 6\% of patients had neither neutropenia nor CRD; this fell to $4 \%$ if children aged $\leq 5$ years were excluded.

We cannot exclude the possibility of undetected VPS13B mutations and in particular genomic deletions of the VPS13B gene as recently described. ${ }^{13}$ Although this hypothesis is very likely in our 2 families in which only one pathogenic mutation was identified, it is unlikely when no pathogenic mutations are identified after genomic sequencing of the entire gene in nonconsanguineous families.

In conclusion, our study showed that CRD and neutropenia appear to be the best predictors for the presence of $V P S 13 B$ mutations. Given the large size of the gene, and since the probability of finding a VPS $13 B$ mutation in the absence of these key features is very low, screening for VPS13B mutations is not recommended unless they are present. Because of the age-dependent onset of CRD, caution should be exercised in young children, in whom followup could be a reasonable alternative. However, VPS13B screening could be offered in such cases when the reproductive context is indicative since there is a $25 \%$ risk of recurrence.

\section{ACKNOWLEDGMENTS}

The authors thank the patients and their families for their participation in the study. The authors also thank Philip Bastable from the "pôle de recherche" of Dijon Hospital for his English review of the manuscript. 


\section{LICENCE FOR PUBLICATION STATEMENT}

The Corresponding Author has the right to grant on behalf of all authors and does grant on behalf of all authors, an exclusive licence on a worldwide basis to the BMJ Publishing Group Ltd to permit this article to be published in JMG and any other BMJPGL products and sublicences such use and exploit all subsidiary rights, as set out in our licence (http://group.bmj.com/products/journals/instructions-for-authors/licence-forms).

\section{COMPETING INTEREST}

None declared 


\section{REFERENCES}

1. Cohen MM, Jr, Hall BD, Smith DW, Graham CB, Lampert KJ. 1973. A new syndrome with hypotonia, obesity, mental deficiency, and facial, oral, ocular and limb anomalies. J Pediatr 83: 280284.

2. Kivitie-Kallio S, Norio R. 2001. Cohen syndrome: Essential features, natural history, and heterogeneity. Am J Med Genet 102:125-135.

3. Chandler KE, Kidd A, Al-Gazali L, Kolehmainen J, Lehesjoki AE, Black GCM, Clayton-Smith J. 2003. Diagnostic criteria, clinical characteristics, and natural history of Cohen syndrome. J Med Genet 40:233-241.

4. Kolehmainen J, Black GCM, Saarinen A, Chandler K, Clayton- Smith J, Traskelin AL, Perveen R, Kivitie-Kallio S, Norio R, Warburg M, Fryns JP, de la Chapelle A, Lehesjoki AE. 2003. Cohen syndrome is caused by mutations in a novel gene, $\mathrm{COH} 1$, encoding a transmembrane protein with a presumed role in vesicle-mediated sorting and intracellular protein transport. Am J Hum Genet 72:1359-1369.

5. Falk MJ, Feiler HS, Neilson DE, Maxwell K, Lee JV, Segall SK, Robin NH, Wilhelmsen KC, Traskelin AL, Kolehmainen J, Lehesjoki AE, Wiznitzer M, Warman ML. 2004. Cohen syndrome in the Ohio Amish. Am J Med Genet Part A 128A: 23-28.

6. Hennies HC, Rauch A, Seifert W, Schumi C, Moser E, Al-Taji E, Tariverdian G, Chrzanowska KH, Krajewska-Walasek M, Rajab A, Giugliani R, Neumann TE, Eckl KM, Karbasiyan M, Reis A, Horn D. 2004. Allelic heterogeneity in the $\mathrm{COHI}$ gene explains clinical variability in Cohen syndrome. Am J Hum Genet 75:138-145.

7. Kolehmainen J, Wilkinson R, Lehesjoki AE, Chandler K, Kivitie-Kallio S, Clayton-Smith J, Traskelin AL, Waris L, Saarinen A, Khan J, Gross-Tsur V, Traboulsi EI, Warburg M, Fryns JP, Norio R, Black GCM, Manson FDC. 2004. Delineation of Cohen syndrome following a large-scale genotype-phenotype screen. Am J Hum Genet 75:122-127.

8. Kondo I, Shimizu A, Asakawa S, Miyamoto K, Yamagata H, Tabara Y, Shimizu N. 2004. COHI analysis and linkage study in two Japanese families with Cohen Syndrome. Clin Genet 67:270-272. 
9. Mochida GH, Rajab A, Eyaid W, Lu A, Al-Nouri D, Kosaki K, Noruzinia M, Sarda P, Ishihara J, Bodell A, Apse K, Walsh CA. 2004. Broader geographical spectrum of Cohen syndrome due to $\mathrm{COHI}$ mutations. J Med Genet 41:e87.

10. Seifert W, Holder-Espinasse M, Spranger S, Hoeltzenbein M, Rossier E, Dollfus H, Lacombe D, Verloes A, Chrzanowska KH, Maegawa GHB, Chitayat D, Kotzot D, Huhle D, Meinecke P, Albrecht B, Mathijssen I, lleheup B, Raile K, Hennies HC, Horn D. 2006. Mutational spectrum of $\mathrm{COH1}$ and clinical heterogeneity in Cohen syndrome. J Med Genet 43:e22.

11. Katzaki E, Pescucci C, Uliana V, Papa FT, Ariani F, Meloni I, Priolo M, Selicorni A, Milani D, Fischetto R, Celle ME, Grasso R, Dallapiccola B, Brancati F, Bordignon M, Tenconi R, Federico A, Mari F, Renieri A, Longo I. 2007. Clinical and molecular characterization of Italian patients affected by Cohen syndrome. J Hum Genet 52:1011-1017.

12. Bugiani M, Gyftodimou Y, Tsimpouka P, Lamantea E, Katzaki E, d'Adamo P, Nakou S, Georgoudi N, Grigoriadou M, Tsina E, Kabolis N, Milani D, Pandelia E, Kokotas H, Gasparini P, Giannoulia-Karantana A, Renieri A, Zeviani M, Petersen MB. 2008. Cohen syndrome resulting from a novel large intragenic $\mathrm{COH} 1$ deletion segregating in an isolated Greek island population. Am J Med Genet A 146A:2221-2226.

13. Balikova I, Lehesjoki AE, de Ravel TJ, Thienpont B, Chandler KE, Clayton-Smith J, Träskelin AL, Fryns JP, Vermeesch JR. 2009. Deletions in the VPS13B (COH1) Gene as a Cause of Cohen Syndrome. Hum Mutat 30(9):E845-54.

14. Seifert W, Holder-Espinasse M, Kühnisch J, Kahrizi K, Tzschach A, Garshasbi M, Najmabadi H, Walter Kuss A, Kress W, Laureys G, Loeys B, Brilstra E, Mancini GM, Dollfus H, Dahan K, Apse K, Hennies HC, Horn D. 2009. Expanded mutational spectrum in Cohen syndrome, tissue expression, and transcript variants of COH1. Hum Mutat 30(2):E404-20.

15. Miller SA, Dykes DD, Polesky H. 1988. A simple salting out procedure for extracting DNA from human nucleated cells. Nucleic Acids Res 16:1215.

16. Den Dunnen JT, Antonarakis SE. 2001. Nomenclature for the description of human sequence variations. Hum Genet 109:121-124. 
17. Travaglini L, Brancati F, Attie-Bitach T, Audollent S, Bertini E, Kaplan J, Perrault I, Iannicelli M, Mancuso B, Rigoli L, Rozet JM, Swistun D, Tolentino J, Dallapiccola B, Gleeson JG, Valente EM; International JSRD Study Group, Zankl A, Leventer R, Grattan-Smith P, Janecke A, D'Hooghe M, Sznajer Y, Van Coster R, Demerleir L, Dias K, Moco C, Moreira A, Kim CA, Maegawa G, Petkovic D, Abdel-Salam GM, Abdel-Aleem A, Zaki MS, Marti I, Quijano-Roy S, Sigaudy S, de Lonlay P, Romano S, Touraine R, Koenig M, Lagier-Tourenne C, Messer J, Collignon P, Wolf N, Philippi H, Kitsiou Tzeli S, Halldorsson S, Johannsdottir J, Ludvigsson P, Phadke SR, Udani V, Stuart B, Magee A, Lev D, Michelson M, Ben-Zeev B, Fischetto R, Benedicenti F, Stanzial F, Borgatti R, Accorsi P, Battaglia S, Fazzi E, Giordano L, Pinelli L, Boccone L, Bigoni S, Ferlini A, Donati MA, Caridi G, Divizia MT, Faravelli F, Ghiggeri G, Pessagno A, Briguglio M, Briuglia S, Salpietro CD, Tortorella G, Adami A, Castorina P, Lalatta F, Marra G, Riva D, Scelsa B, Spaccini L, Uziel G, Del Giudice E, Laverda AM, Ludwig K, Permunian A, Suppiej A, Signorini S, Uggetti C, Battini R, Di Giacomo M, Cilio MR, Di Sabato ML, Leuzzi V, Parisi P, Pollazzon M, Silengo M, De Vescovi R, Greco D, Romano C, Cazzagon M, Simonati A, Al-Tawari AA, Bastaki L, Mégarbané A, Sabolic Avramovska V, de Jong MM, Stromme P, Koul R, Rajab A, Azam M, Barbot C, Martorell Sampol L, Rodriguez B, Pascual-Castroviejo I, Teber S, Anlar B, Comu S, Karaca E, Kayserili H, Yüksel A, Akcakus M, Al Gazali L, Sztriha L, Nicholl D, Woods CG, Bennett C, Hurst J, Sheridan E, Barnicoat A, Hennekam R, Lees M, Blair E, Bernes S, Sanchez H, Clark AE, DeMarco E, Donahue C, Sherr E, Hahn J, Sanger TD, Gallager TE, Dobyns WB, Daugherty C, Krishnamoorthy KS, Sarco D, Walsh CA, McKanna T, Milisa J, Chung WK, De Vivo DC, Raynes H, Schubert R, Seward A, Brooks DG, Goldstein A, Caldwell J, Finsecke E, Maria BL, Holden K, Cruse RP, Swoboda KJ, Viskochil D. 2009. Expanding CEP290 mutational spectrum in ciliopathies. Am J Med Genet A 149:2173-2180.

18. Bhatti MT. 2006. Retinitis pigmentosa, pigmentary retinopathies, and neurologic diseases. Curr Neurol Neurosci Rep 6:403-413.

19. Hartong DT, Berson EL, Dryja TP. 2006. Retinitis pigmentosa. Lancet 368 :1795-1809.

20. Chandler KE, Biswas S, Lloyd IC, Parry N, Clayton-Smith J, Black GC. 2002. The ophthalmic findings in Cohen syndrome. Br J Ophthalmol 86:1395-1398. 
Legends to supplementary figures

Supplementary figure 1: Sequence alignment of conserved region including the position 1636 where the amino acid isoleucine (I) is mutated to asparagine (N) in VPS13-like proteins in different species. This position is indicated by an $(*)$ and always occupied by a non-polar amino acid residue.

Supplementary figure 2: Sequence analysis of $\mathrm{COH}$ l gene exon 31 in probands from the family with Cohen syndrome. The homozygous nature of the missense mutation c.4907T>A in the probands and the heterozygous nature of the same mutation in the consanguineous parents are shown. 
Table 1: Clinical features of the CS spectrum in patients with or without VPS13B gene mutations

\begin{tabular}{lccc}
\hline \multicolumn{1}{c}{ Clinical features } & $\begin{array}{c}\text { Patients with } \\
\text { VPS13B } \\
\text { mutations* }\end{array}$ & $\begin{array}{c}\text { Patients without } \\
\text { VPS13B } \\
\text { mutations* }\end{array}$ & p \\
\hline Mean age at screening & $18 \pm 12$ years & $16 \pm 7$ years & \\
\hline Mental retardation & $12 / 12(100 \%)$ & $22 / 22(100 \%)$ & NS \\
Compatible facial gestalt & $12 / 12(100 \%)$ & $17 / 22(77 \%)$ & NS \\
Microcephaly & $11 / 11(100 \%)$ & $10 / 21(48 \%)$ & 0.0045 \\
Joint hyperextensiblity & $9 / 11(82 \%)$ & $7 / 14(50 \%)$ & NS \\
Slender extremities/ Tapering fingers & $12 / 12(100 \%)$ & $19 / 22(86 \%)$ & NS \\
Truncal obesity & $11 / 12(92 \%)$ & $18 / 22(82 \%)$ & NS \\
Myopia & $9 / 10(90 \%)$ & $11 / 22(50 \%)$ & 0.049 \\
CRD & $\mathbf{1 1 / 1 2}(\mathbf{9 2 \%})$ & $\mathbf{6 / 1 9}(\mathbf{3 2 \%})$ & $\mathbf{0 . 0 0 2 3}$ \\
Neutropenia & $\mathbf{1 1 / 1 2}(\mathbf{9 2 \%})$ & $\mathbf{1 / 2 1}(\mathbf{5 \%})$ & $<\mathbf{0 . 0 0 1}$ \\
\hline $\begin{array}{l}\text { Fulfillment of Kolehmainen's criteria } \\
\text { [2004] }\end{array}$ & $12 / 12(100 \%)$ & $5 / 22(23 \%)$ & $<0.001$ \\
\hline
\end{tabular}

NS: not statistically significant

* $\mathrm{N}$ positive/ $\mathrm{N}$ assessed patients 
Table 2: Mutations identified in VPS13B gene from 12 patients (8 families) with Cohen Syndrome

\begin{tabular}{|l|l|l|l|}
\hline $\begin{array}{l}\text { Patients } \\
\text { (Family) }\end{array}$ & Nucleotide change (amino-acid change) & Exon & Source \\
\hline P1 & c.436C>T (p.R146X) & 5 & Novel \\
F1 & Second mutation not found & 56 & Novel \\
\hline P2, P3 & c.10139_10143dupCGCCA (p.A3380fsX3396) & & \\
F2 & Second mutation not found & 9 & Novel \\
\hline P7 & c.1220delA (p.Q407fsX418) & 40 & Novel \\
F6 & c.7286delT (p.V2429fsX2430) & 31 & Novel \\
\hline P8, P9 & c.4907T>A (p.I1636N) & 31 & Novel \\
F7 & c.4907T>A (p.I1636N) & 15 & 4,10 \\
\hline P10, P11 & c.2074C>T(p.R692X) & 34 & 4,10 \\
F8 & c.5426_5427dupAG (p.Q1810fsX1830) & 23 & Novel \\
\hline P15 & c.3427C>T (p.R1143X) & 56 & Novel \\
F11 & [c.10880C>T; & & \\
& c.10883_10900delCGAGGCAGCTTGTGCACG]* & & \\
\hline P18, P19 & c.9136_917; p.A3628_H3633del]) & 7 & Novel \\
F14 & c.1006C>T (p.Q336X) & 8 & Novel \\
\hline P21 & c.477_480delACTA (p.I159fsX21) & 5 & Novel \\
F16 & c.11859_11860insAA(p.N3954fsX60)) & 62 & Novel \\
\hline
\end{tabular}

*These two sequence variations were found on the same allele 
Table 3: Study of the occurrence of CRD and/or neutropenia in patients with VPS13B mutations reported in the literature and in the present series $(\mathrm{N}$ positive/ $\mathrm{N}$ assessed patients)

\section{CRD Neutropenia CRD or neutropenia}

Kolehmainen et al., 2003

$31 / 31$

$31 / 31$

$31 / 31$

Kolehmainen et al., 2004

$28 / 29$

$25 / 26$

$29 / 29$

Falk et al., 2004

$8 / 8^{*}$

NR

$8 / 8$

Hennies et al., 2004

$13 / 20 * *$

$10 / 18$

$17 / 20$

Kondo et al., 2004

$2 / 2$

$2 / 2$

$2 / 2$

Mochida et al., 2006

$4 / 7 *$

$3 / 7$

$5 / 7$

Seifert et al., 2006

$13 / 21 * * *$

$14 / 16$

$16 / 21$

Katzaki et al., 2007

$9 / 10^{*}$

$9 / 10$

$10 / 10$

Seifert et al., 2009

$11 / 12 * * * *$

$6 / 11$

$12 / 12$

Balikova et al., 2009

$8 / 8$

$7 / 8$

$8 / 8$

Present series

$11 / 12 * * * * *$

$11 / 12$

$12 / 12$

Total
(\% of positive/assessed
patients)

$138 / 160(86 \%)$

$128 / 139(92 \%)$

if children aged $\leq 5$

$118 / 141$

$150 / 160(94 \%)$

years are excluded

$(84 \%)$ $133 / 139(96 \%)$

if children aged $\leq 5$ years
are excluded

NR: not reported;

$*$ including 1 patient aged $\leq 5$ years; ** including 7 patients aged $\leq 5$ years; *** including 6 patients aged $\leq$ 5 years; $* * * *$ including 3 patients aged $\leq 5$ years; $* * * * *$ including 2 patients aged $\leq 5$ years. 